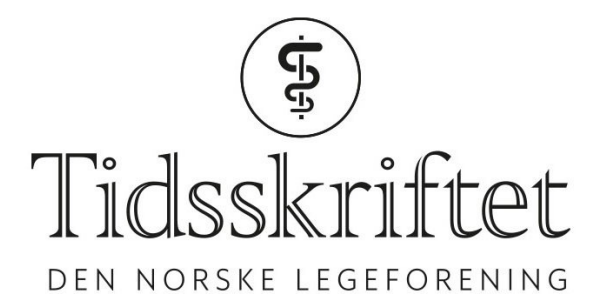

DEN NORSKE LEGEFORENING

\title{
A-S. Øyen og medarbeidere svarer
}

KOMMENTAR

\section{ANNE-SIRI ØYEN}

E-post: anne-siri.oyen@lds.no

Anne-Siri Øyen er psykologspesialist.

Ingen oppgitte interessekonflikter.

\section{BENTE ULLEBERG}

Bente Ulleberg er helsesøster med videreutdanning i sped- og småbarns psykiske helse ved Nic Waals Institutt, Lovisenberg Diakonale Sykehus. Ingen oppgitte interessekonflikter.

\section{PAUL SANGAR}

Paul Sangar er lege i spesialisering i barne- og ungdomspsykiatri og konstituert overlege ved Barneseksjonen psykisk helse, Enhet B, Oslo universitetssykehus, Ullevål.

Ingen oppgitte interessekonflikter.

\section{SEAN WALLACE}

Sean Wallace er spesialist i barnesykdommer og overlege ved Barneavdeling for nevrofag, Oslo universitetssykehus. Ingen oppgitte interessekonflikter.

\section{HENRIK HOLMSTR $\varnothing M$}

Henrik Holmstrøm er spesialist i barnesykdommer og overlege ved Barnekardiologisk avdeling, Barne- og ungdomsklinikken, Oslo universitetssykehus og professor ved Institutt for klinisk medisin, Universitetet i Oslo.

Ingen oppgitte interessekonflikter.

Vi takker Steinar Konradsen og Henriette Konradsen for kommentarer. Vi er helt enige i at tidlig innsats er viktig for barn som strever.

Det vi ønsket å trekke frem med denne kasuistikken er hvor viktig det er at barn med hjertefeil og deres foreldre blir fulgt opp fra fødsel, slik "Veileder for tverrfaglig oppfølging av barn med hjertefeil" understreker (1). Det aller beste ville være om gutten og familien hadde fått den anbefalte oppfølging helt fra starten av. Når dette ikke var gjort, mener vi at det tverrfaglige samarbeidet rundt utredning og behandling var viktig. Utredningene viste at han ikke hadde de klassiske vanskene man ser hos barn med medfødt hjertefeil, og fokus i behandlingen ble veiledning til foreldre og barnehage.

$\emptyset \mathrm{kte}$ ressurser i førstelinjen vil kunne bidra til at barn og familier får hjelp tidlig. Økt samarbeid mellom førstelinjen og spesialisthelsetjenesten vil også være positivt for de som trenger dette. Når det gjelder barn med hjertefeil har rollefordelingen mellom ulike nivåer i helsetjenesten vært uklare. Vi håper at denne kasuistikken vil bidra til økt forståelse og 
kunnskap, slik at disse barna og deres foreldre får den støtten de trenger gjennom hele barndommen.

\section{LITTERATUR:}

1. Veileder for tverrfaglig oppfølging av hjertebarn i primær- og spesialisthelsetjenesten. Oslo: Norsk barnelegeforening, 2015 .

http://legeforeningen.no/Fagmed/Norsk-barnelegeforening/Interessegrupper/Ductusno/Fag/Oppfolgi ng-rutiner1/Veileder-for-tverrfaglig-oppfolging-av-hjertebarn-i-primar-og-spesialisthelsetjenesten/ (9.10.2017).

Publisert: 8. januar 2018. Tidsskr Nor Legeforen. DOI: 10.4045/tidsskr.17.1091

(C) Tidsskrift for Den norske legeforening 2020. Lastet ned fra tidsskriftet.no 